\title{
TCF7L2 rs7903146 Gene Variation Is Associated with Risk of Type 2 Diabetes in Turkish Population
}

Ibrahim Halil Demirsoy ${ }^{1^{*}}$, Nurcan Aras ${ }^{1}$ and Umit Cinkır ${ }^{2}$

${ }^{1}$ Department of Medical Biology, Mersin University,Mersin, Turkey

${ }^{2}$ Department of Endocrinology and Metabolism,Mersin University,Mersin, Turkey

*Corresponding authors: Ibrahim Halil Demirsoy, Department of Medical Biology, Merisin University, Mersin, Turkey, E-mail:ibrahimdemirsoy@gmail.com

Rec date: April 18, 2016; Acc date: May 07, 2016; Pub date: May 15, 2016

Copyright: ( 2016 Demirsoy IH. This is an open-access article distributed under the terms of the Creative Commons Attribution License, which permits unrestricted use, distribution, and reproduction in any medium, provided the original author and source are credited

\begin{abstract}
Type 2 diabetes (T2D) results from combination of environmental factors and genetic determinants. Transcription factor 7-like 2 (TCF7L2) genes have been reported that it plays important role in T2D pathogenesis. In addition, TCF7L2 gene polymorphisms have been linked to T2D through many European populations. In the present study, we investigated TCF7L2 polymorphisms in healthy individuals and T2D patients and aimed to see whether TCF7L2 polymorphisms are associated with T2D in the Turkish population. We genotyped two SNPs of TCF7L2 gene, rs7903146 and rs12255372 in 100 healthy individuals and 100 patients. As a result of the genotype and allele distributions, we found that there were significantly associations between the TCF7L2 rs7903146 and risk of T2D $(p=0.0172)$ in Turkish Population. However, there was no association for TCF7L2 rs12255372 $(p=0.395)$ but GT genotype was higher in patient groups $(p=0.0250)$. Similarly, our data shows that individuals who carry TCF7L2 rs7903146 polymorphism have significant risk of T2D in Turkish population.
\end{abstract}

Keywords Polymorphism; Association; T2D; TCF7L2

\section{Introduction}

T2D is a multifactorial metabolic disease which is characterized by hyperglycemia. Inadequate secretion of insulin or resistance to secreted insulin play important role in progression of T2D [1,2]. It also causes to various complications including cardiovascular and endothelial diseases $[3,4]$. The prevalence of T2D is increasing every year in worldwide. It has been reported that 366 million people were affected by diabetes in 2011 and expected to be double within next 20 years in the world $[5,6]$.It has been reported that prevalence of diabetes in Turkey raised up to $14.58 \%$ in 2013 [7].

Genome wide analysis revealed that many genes involved in type-2 diabetes pathogenesis [8]. Especially, Transcription factor 7-like 2 (TCF7L2) gene is thought to be best candidate gene involved in from impairment of insulin secretion to development of T2D [9]. In addition, strong association between TCF7L2 polymorphism and T2D was reported in European populations [10]. The transcription factor 7 like 2 (TCF7L2) gene is an enteroendocrine transcription factor, which is localized to chromosome $10 \mathrm{q}$ and important component of Wnt signaling pathway [11]. Stimulation of Wnt catenin subsequently causes to assemble of $\beta$-catenin with BCL9, translocation into the nucleus and forms an active form with TCF7L2 [12,13]. The complex result in Wnt target genes activation that involves in cell proliferation, apoptosis and tissue invasion [14].

TCF7L2 gene play important role in T2D by regulating adipogenesis, myogenesis and pancreatic islands. It has an effect on function of beta cells and granules responsible for insulin secretion, regulates expression of protein involved in exocytosis of insulin granules [15]. It has been reported that individuals who carries risk alleles for SNPs within TCF7L2 showed impaired insulin secretion, increase in gastric inhibitor and impairment in glucose metabolism
[16]. However, molecular mechanism of impaired insulin secretion due to TCF7L2 gene polymorphism is still not known [17]. Based on this background, we aimed to investigate whether TC7L2 polymorphisms are associated with T2D in Turkish patients.

\section{Material and Methods}

\section{Subjects}

The study includes 100 patients who were diagnosed as T2D in Mersin University, Faculty of Medicine, and Department of Endocrinology. Total of 100 individuals were recruited to this study as control group. The study was approved by the ethics committee of the Mersin University.

\section{Genotyping of polymorphisms in TCF7L2}

About 6-7 ml peripheral blood was collected in 2\% EDTAcontaining tubes and genomic DNA was extracted from leukocytes by high pure template preparation kit (Roche, Switzerland). Two SNPs of the TCF7L2, rs7903146 and rs12255372 were genotyped by real time PCR using the Light Cycler DNA Master Hybridization probes kit. The primer and probe sequences were given in Table 1 . The PCR conditions for TCF7L2 genotypes were lay out as: $4 \mathrm{mmol} / \mathrm{l} \mathrm{MgCI}, 0,2 \mu \mathrm{mol} / \mathrm{l}$ of each PCR primers and $5 \mu \mathrm{L}$ of the Light Cycler DNA Master Hybridization Mix and $50 \mathrm{ng}$ of genomic DNA in a final volume of $50 \mu \mathrm{L}$.

\section{Statistical analysis}

Chi- Square test was used to determine the genotype frequency of TCF7L2 polymorphisms in patient and control groups. The association between TCF7L2 polymorphisms and T2D was modelled in terms of binary logistic regression analysis. To determine $\mathrm{T} 2 \mathrm{D}$ risk for the 
Citation: Demirsoy IH, Aras N, Cinkir U (2016) TCF7L2 rs7903146 Gene Variation Is Associated with Risk of Type 2 Diabetes in Turkish Population. J Clin Med Genomics 4: 141 . doi: 10.4172/2472-128X.1000141

Page 2 of 3

genotypes Odds ratio (OR) and 95\% confidence interval (95\%) were calculated. Then, values of $\mathrm{p} \leq 0.05$ was considered as the meaningful level and SPSS version 11.5 software program was used for statistical analysis.

\section{Results}

A total of 100 patients with $\mathrm{T} 2 \mathrm{D}$ (male $=59$, female $=41$, mean age: $54,24 \pm 16,52$ years) and 100 control groups (male $=56$, femal $=44$ years) participated in this study. Frequency of genotypes for rs7903146 polymorphism was shown in Table 2. CC, CT and TT genotype percentage were $58 \%, 10 \%$ and $32 \%$ in controls, $36 \%, 22 \%$ and $42 \%$ in patients groups. There was significant difference between patients and controls for genotype frequency rs7903146 polymorphism $(\mathrm{p}<0.05)$. However, frequency of genotypes for rs12255372, GG, GT and TT were $82 \%, 9 \%$ and $9 \%$ in controls, $69 \%, 20 \%$ and $11 \%$ in patients groups. No difference was found between control and patient groups $(\mathrm{p}>0.05)$. However, there was significant difference between control and patient group in GT genotype frequency $(\mathrm{p}<0.05)$ (Tables 1-3).

\begin{tabular}{|l|l|l|l|}
\hline Parameter & Patients & Controls & p- Value \\
\hline $\mathrm{n}$ (total) & 100 & 100 & \\
\hline Age (years) & 54,24 & 51,32 & 0.189 \\
\hline Gender & 41 & 44 & 0.775 \\
\hline Female (\%) & 59 & 56 & \\
\hline Male $\mathrm{n}(\%)$ & & & \\
\hline
\end{tabular}

Table 1: The number of controls and patients according to age and gender ( $\mathrm{n}$ - number of sample)

\begin{tabular}{|l|l|l|}
\hline Gene & PCR Primers & Hybridization Probes \\
\hline \multirow{4}{*}{ rs7903146 } & 5'-AGAGCTAAGCACTTTTTAGGT -3' & 5'-TAGAGAGCTAAGCACTTTTTAGATA[C/T] \\
\cline { 2 - 3 } & 5'- GATGAAATGTAGCAGTGAAGT -3' & TATATAATTTAATTGCCGTATGAGG -3' \\
\hline \multirow{2}{*}{ rs12255372 } & 5'- CCAGGAATATCCAGGCAAGGAT -3' & 5'- TGCCCAGGAATATCCAGGCAAGAAT[G/T] \\
\cline { 2 - 3 } & 5'-GGCATTCAAATGGAGGCTGA -3' & ACCATATTCTGATAATTACTCAGGC -3' \\
\hline
\end{tabular}

Table 2: The sequence of primers and probes for rs7903146 and rs12255372

\begin{tabular}{|l|l|l|l|}
\hline $\begin{array}{l}\text { Genotype OR } \\
\text { (95\%Cl) }\end{array}$ & Healthy Controls & Cases with T2DM & X2 \\
\hline & N (\%) & N (\%) & p value \\
\hline (rs7903146) & 58 & 36 & $\mathbf{0 . 0 1 7 2}$ \\
\hline CC ( Reference) & 10 & 22 & $\mathbf{3 . 2 2 2}$ \\
\hline CT (1.39-7.42) & 32 & 42 & $\mathbf{2 . 0 5}$ \\
\hline TT (1.11- 3.80) & 32 & & $\mathbf{0 . 1 0 4 1}$ \\
\hline (rs7903146) & \multicolumn{3}{|l|}{} \\
\hline GG ( Reference) & 82 & 69 & $\mathbf{1 . 4 5 2}$ \\
\hline GT [2.641(1.13-6.17)] & 9 & 20 & 11 \\
\hline TT (0.57- 3.71) & 9 & \multicolumn{2}{|l}{} \\
\hline
\end{tabular}

Table 3: Analysis of TCF7L2 SNPs genotype frequency in controls and T2D patients (Note: Statistically important results are shown as bold)

between the TCF7L2 rs7903146, rs12255372 and risk of T2DM [22-24]. However, there are some studies suggest that no association between TCF7L2 rs12255372 and risk of T2D [25].

In our study, there was significant difference between patient and control groups on rs7903146 $(\mathrm{C} / \mathrm{T})$ polymorphism $(\mathrm{p}=0.0172)$. The number of TT mutant genotype in patients group is more than twice the number in control groups. This result suggests that individuals who carry this mutant allele have more risk of developing of T2D. However, there was no significant difference for $\operatorname{rs} 12255372$ (G/T) polymorphism ( $\mathrm{p}=0.1041)$. Surprisingly, GT genotype was higher in patient groups $(\mathrm{p}=0.0250)$. This results shows that it might be associated with T2D if the number of sample is increased.

Jyothi et al. [26] studied TCF7L2 gene polymorphisms on 758 T2D patients and 621 controls. They found that significant association between T2D and rs7903146 (OR 1.88, p<0.001) and rs12255372 (OR $1.50, \mathrm{p}<0.001$ ). Sladek et al. [21] performed 392,935 SNP analyses on 1363 French populations with T2D. Similarly, they reported that especially TCF7L2 rs7903146 gene variant has highly significant effect on developing of T2DM ( $\mathrm{p}=3.2 \times 10-17)$. Mayans et al. [27] performed similar study on 872 T2D patients and 857 controls in Swedish populations. They found significant associations between TCF7L2 polymorphism and T2D (rs7901346, $\mathrm{P}=0.00002$; and rs12255372, $\mathrm{P}=0.000004)$. TCF7L2 have been also reported to be associates with different types of cancer. Chen et al. [28] studied TCF7L2 gene polymorphism on different types of cancer in American population. As result of Meta analyses, they found that especially rs7903146 have significant association in breast, lung prostate and colon cancer.

Regarding of all those results, rs79013146 gene polymorphism is a major risk factor almost all ethnicity. This shows that TCF7L2 is one of the important genes for susceptibility to T2D. In addition, finding of relation between TCF7L2 polymorphisms and different types of cancer 
Citation: Demirsoy IH, Aras N, Cinkir U (2016) TCF7L2 rs7903146 Gene Variation Is Associated with Risk of Type 2 Diabetes in Turkish Population. J Clin Med Genomics 4: 141 . doi: 10.4172/2472-128X.1000141

Page 3 of 3

shows that it is also susceptible gene to cancer. If the number of study with different ethnicity is increased on this gene, it will be helpful to enlighten of association between cancer and diabetes. In conclusion, our data show that significant association between TCF7L2 rs7903146 and T2D risk. However, further studies with larger number will be required to confirm our data. In addition, there are other factors including age, sex, alcohol using, and ethnicity contributing to progress of T2D. Those factors may affect the genes and predispose individuals to $\mathrm{T} 2 \mathrm{D}$.

\section{Acknowledgments}

This research was supported by the Unit of Scientific Research Projects of Mersin University (BAP-SBE TTB (IHD) 2013-4 YL), Turkey.

\section{Conflict of Interest}

No conflicts of interests were disclosed by the authors.

\section{ABBREVIATIONS}

T2D Type 2 diabetes

DM Diabetus mellitus

EDTA Ethylene diamine tetraacetic acid

OR Odds ratio

TCF7L2 Transcription factor 7-like 2

\section{References}

1. Lin Y, Sun Z (2010) Current views on type 2 diabetes. Journal of Endocrinology 204: 1-11.

2. Kyrou I, Kumar S (2010) Weight management in overweight and obese patients with type 2 diabetes mellitus. The British Journal of Diabetes and Vascular Disease 10: 274-278.

3. Ali AR, Mzayek F, Rastam S, Fouad MF, O’Flaherty M (2013) Forecasting future prevalence of type 2 diabetes mellitus in Syria. BMC Public Health 13: 507-516.

4. Desouza C, Fonseca V (2009) Therapeutic targets to reduce cardiovascular disease in type 2 diabetes. Nature reviews 8: 361-367.

5. Nath D, Heemels MT, Anson L (2006) Reviews on obesity and diabetes. Nature 444: 839-888.

6. Whiting D, Guariguata L, Weil C, Shaw J (2011) IDF diabetes atlas: Global estimates of the prevalence of diabetes for 2011 and 2030. Diabetes Research and Clinical Practise 94: 311-321.

7. http://www.diabetesatlas.org/

8. Frayling TM (2007) Genome-wide association studies provide new insights into type 2 diabetes aetiology. Nat Rev Genet 8: 657-662.

9. Elbein S (2009) Genetic factors contributing to type 2 diabetes across ethnicities. J Diabetes Sci Technol 3: 685-689.
10. Grant SF (2006) Variant of transcription factor 7-like 2 (TCF7L2) gene confers risk of type 2 diabetes. Nat Genet 38: 320-323.

11. Castrop J, Norren KV, Clevers H (1992) A gene family of HMG-box transcription factors with homology to TCF-1. Nucleic Acids Res 20: 611-617.

12. Yi F, Brubaker PL, Jin T (2005) TCF-4 mediates cell type-specific regulation of proglucagon gene expression by beta-catenin and glycogen synthase kinase-3beta. J Biol Chem 280: 1457-1464.

13. Klaus A, Birchmeier W (2008) Wnt signalling and its impact on development and cancer. Nat Rev Cancer 8: 387-398.

14. Zhang KS, Zhou Q, Wang YF, Liang L (2013) Inhibition of Wnt Signaling induces cell apoptosis and suppresses cell proliferation in cholangiocarcinoma cells. Oncol Rep 30: 1430-1438.

15. Xavier GS, Loder MK, McDonald A, Tarasov AI, Carzaniga R, et al. (2009) TCF7L2 regulates late events in insulin secretion from pancreatic islet beta-cells. Diabetes 58: 894-905.

16. Schafer SA, Tschritter O, Machicao F, Thamer C, Stefan N, et al. (2007) Impaired glucagon-like peptide-1-induced insulin secretion in carriers of transcription factor 7-like 2 (TCF7L2) gene polymorphisms. Diabetologia 50: 2443-2450.

17. Florez JC, Jablonski KA, Bayley N, Pollin TI, de Bakker PI, et al. TCF7L2 polymorphisms and progression to diabetes in the Diabetes Prevention Program. N Engl J Med 355: 241-250.

18. Jin T (2008) The WNT signalling pathway and diabetes mellitus. Diabetologia 51: 1771-1780.

19. Yi F, Brubaker PL, Jin T (2005) TCF-4 mediates cell type-specific regulation of proglucagon gene expression by beta-catenin and glycogen synthase kinase-3beta. J Biol Chem 280: 1457-1464.

20. Smith U (2007) TCF7L2 and type 2 diabetes-we WNT to know. Diabetologia 50: 5-7.

21. Gupta V, Khadgawat R, Saraswathy KN, Sachdeva MP, Kalla AK (2008) Emergence of TCF7L2 as a most promising gene in predisposition of Diabetes Type II. Int J Hum Genet 8: 199-215.

22. Sladek R, Rocheleau G, Rung J, Dina C (2007) A genome-wide association study identifies novel risk loci for type 2 diabetes. Nature 445 : 881-885.

23. Salem A, Ajina M, Suissi M (2011) Polymorhisms of transcription factor -7-like 2 (TCF7L2) gene in Tunisian women with plycystic ovary syndrome (PCOS). Gene 533: 551-557.

24. Vliet-Ostaptchouk JV, Shiri-Sverdlov R, Zhernakova A, Strengman E, Haeften TW, et al. (2007) Association of variants of TCF7L2 with susceptibility to type 2 diabetes in the Dutch Breda cohort. Diabetologia 50: 59-62.

25. Horikoshi M, Hara K, Ito C, Nagai R, Froguel P, et al. (2007) A genetic variation of the transcription factor 7-like 2 gene is associated with risk of type 2 diabetes in the Japanese population. Diabetologia 50: 747-751.

26. Jyothi KU, Jayaraj M, Subburaj KS, Prasad KJ, Kumuda I et al. (2013) Association of TCF7L2 Gene Polymorphisms with T2DM in the Population of Hyderabad, India. PLoS ONE 8: e60212.

27. Mayans S, Lackovic K, Lindgren P, Ruikka K, Agren A, et al. (2007) TCF7L2 polymorphisms are associated with type 2 diabetes in northern Sweden. European Journal of Human Genetics 15: 342-346.

28. Chen J, Yuan T, Liu M, Chen P (2013) Association between TCF7L2 Gene polymorphism and Cancer risk: A meta-analysis. Plos one 8: e71730. 